sciendo Порівняльна професійна педагогіка 9(2)/2019 Comparative Professional Pedagogy 9(2)/2019

DOI: $10.2478 /$ rpp-2019-0018

Postgraduate Student, BOHDAN BRAIKO

Khmelnytskyi National University

Address: 11 Instytutska St., Khmelnytskyi, 29016, Ukraine

E-mail: comprofped@gmail.com

\title{
THE CONTENT OF PROFESSIONAL TRAINING OF MASTERS IN NATIONAL SECURITY AT THE UK UNIVERSITIES
}

\begin{abstract}
The article deals with the content of training Masters in National Security at the UK universities. The problem of the state's national security in the context of the state's general development and the realization of its national interests has been actualized. It is noted that maintaining the national interests of any state world provides an adequate response to the challenges and threats of today, namely the implementation of an effective national security policy. It is found that the UK's national security strategy lists all the key threats that the government believes are threatening the state. Terrorism has been the top problem since the terrorist attacks in London in 2007. The proliferation of nuclear weapons and other types of weapons of mass destruction causes much anxiety, too. The UK strategy also includes threats such as transnational organized crime, global instability and conflictogenity (in the Middle East and Africa), global climate change, energy shortages, poverty, etc. The conducted research proves that the UK seeks to identify and eliminate such threats as transnational organized crime, global instability and conflictogenity, global climate change, energy shortages, poverty, etc. The UK National Security Strategy is based on such key values as human rights, the rule of law, a lawful and responsible government, justice, freedom, tolerance and equal opportunity for all. As a result, the UK universities aim to diversify professional training of specialists in national security incorporating into the field such areas as peace or war studies, conflict studies, terrorism, insurgency, etc. The content of professional training for national security specialists, namely masters, provided by King's College London, the University of Leeds and Coventry University are characterized by the following features: adherence to the nation-wide principles of national security, the conceptual diversity of degree programmes (national security studies; peace and conflict studies; security, terrorism and insurgency), focus on humanities, professionoriented compulsory modules, a wide range of optional courses, flexible combination of study and work and personal commitments, research challenges, taking into account the dilemmas and challenges of globalization and integration, promotion of human rights, etc. The relevant recommendations have been singled out to improve the content of professional training for such specialists at Ukrainian universities.
\end{abstract}

Keywords: national security specialist, master's degree, national security studies, professional training, universities, content, the UK.

\footnotetext{
АНОТАЦІЯ

Стаття присвячена проблемі змісту підготовки магістрів начіональної безпеки в університетах Великої Британії. Зактуалізовано проблему начіональної безпеки держави у контексті загального розвитку країни та реалізачії ї̈ національних
} 
sciendo Порівняльна професійна педагогіка 9(2)/2019 Comparative Professional Pedagogy 9(2)/2019

інтересів. Зазначено, щзо забезпечення начіональних інтересів будь-якої держави світу передбачає адекватне реагування на виклики та загрози сучасності, а саме проведення ефективної політики національної безпеки. 3'ясовано, щяо стратегія національної безпеки Великої Британії перераховує усі ключові загрози, які, на думку уряду, загрожують державі. На першому місиі перебуває тероризм, щзо є наслідком терористичних атак у Лондоні в 2007 рочі. На другому місиі є загроза поширення ядерної зброї та інших видів зброї масового знищення. Стратегія Великої Британї передбачає також такі загрози, як трансначіональна організована злочинність, глобальна нестабільність $i$ конфліктогенність (на Близькому Сході $i$ в Африиі), глобальна зміна клімату, нестача енергії, бідність та ін. Здійснене дослідження свідчить про те, щзо університети Великої Британії прагнуть диверсифікувати професійну підготовку фахівиів начіональної безпеки, упроваджуючи у неї такі предметні сфери, як встановлення миру та урегулювання конфліктів, тероризм, толерантність, кібер безпека, політика брексіту, контртероризм, американська зовнішня політика, політика ізраӥльсько-палестинського конфлікту, теоретичні підходи в міжнародних відносинах, громадянська війна та внутрішньодержавний конфлікт, сучасна політика Близького Сходу, європейський аналіз оборони та безпеки, тощяо. Зміст професійної підготовки фахівців з національної безпеки, а саме магістрів національної безпеки, здійснюваної Королівським коледжем у Лондоні, Університетом Лідса та Університетом Ковентрі, передбачає дотримання загальнонаціональних принципів національної безпеки, концептуальне розмаїття освітніх програм з національної безпеки, професійно-орієнтовані обов'язкові модулі, широкий спектр вибіркових модулів, врахування викликів глобалізації та інтеграції, просування прав людини та ін. Окреслено рекомендачії для покращення змісту професійної підготовки фахівців з національної безпеки в українських університетах.

Ключові слова: фахівець з начіональної безпеки, магістерський рівень, студії з національної безпеки, професійна підготовка, університети, зміст, Велика Британія.

\section{INTRODUCTION}

The problem of national security has always been a concern for all humanity in the process of its civilization development. After the two world wars and the end of the cold war, they did not justify their hopes for reducing the number of threats to national and international security. Interstate conflicts, terrorist acts, the threat of nuclear war, emergencies of anthropogenic and natural character continue to pose a great danger in the 21 st century. The list of actual and potential threats to national and international security is far from limited by the above-mentioned examples. Under these circumstances, the safeguarding of national interests of any state in the world provides an adequate response to the challenges and threats of today, that is, the implementation of an effective national security policy.

The difficult political situation in Ukraine and the threat to Ukrainian statehood necessitate the strengthening of defence capabilities, including through improving the quality of training highly qualified national security specialists. The Ukrainian government is now updating the system of combat and special training of specialists in national security and defence sector of Ukraine, which involves improving the content of such training, introducing an integrated system of education, combat and special training of specialists in national security and defence sector and involving instructors from the member states of NATO and the EU, forming a new culture of security, preserving the specialization and 
sciendo Порівняльна професійна педагогіка 9(2)/2019 Comparative Professional Pedagogy 9(2)/2019

individualization of the training system if needed. Thus, professional training of highly qualified national security specialists is one of the most relevant issues of ensuring law and order, protecting human rights and the rule of law in the state.

The success of these specialists' training in many respects depends on the ability to take into account foreign experience in professional training of national security specialists and implement the most effective achievements and areas in professional training of national security specialists in Ukraine. The author of the article believes that one should pay considerable attention to the UK experience in ensuring professional training of national security specialists since the main issue of the country's concept of national security is not only its external form but also the specific content, the definition of new threats and national interests, etc.

\section{THE AIM OF THE STUDY}

The paper aims to study and analyze the content of professional training for national security specialists in UK universities and single out some positive aspects of such experience in order to implement it at Ukranian universities.

\section{THEORETICAL FRAMEWORK AND RESEARCH METHODS}

The UK National Security Strategy lists all the key threats that, in the government's view, are threatening the state. Terrorism has been the top problem since the terrorist attacks in London in 2007. The proliferation of nuclear weapons and other types of weapons of mass destruction causes much anxiety, too. The UK National Security Strategy also includes such threats as transnational organized crime, global instability and conflictogenity (in the Middle East and Africa), global climate change, energy shortages, poverty, etc. According to it, national security for the UK is not only the mere protection of the state and its vital interests from the attacks of other states. Over the past decades, the understanding of it has rather expanded. Now, national security, among other things, must also pay attention to the threats to the way of life of British society and the integrity of the state. In the UK National Security Strategy, the approach to national security is based on a number of key values. They include human rights, the rule of law, a lawful and responsible government, justice, freedom, tolerance and equal opportunity for all. These values form the basis of Britain's security, well-being and prosperity. Bearing in mind the joint efforts to confront challenges and threats, the UK National Security strategy is aimed at an interaction at the level of such integration structures, such as the UN, the European Union and NATO. Their efforts are considered by the UK to be sufficient to address security concerns.

The UK National Security Strategy foresees that Britain is in a favourable position to benefit from globalization. However, it takes on the responsibility to control the threats posed by globalization. Thus, threats are divided into the following categories: economic (threats to open markets, global financial stability, potential threats to international trade); technological (Internet); demographic (population growth and related problems with food and water shortages, rising unemployment, migration) (HM Government, 2010).

Some British strategists believe that instability and conflicts abroad are among the most important threats to UK national security. In those areas, where the government is absent or weak, for example in Somalia or Yemen, such phenomena as terrorism, organized crime and piracy are spreading. The fight against terrorism was reflected in the concrete measures taken by the government of Mr Cameron. The Terrorism Prevention and Investigation Measures Act was adopted in 2011, whereas the Counter-Terrorism and Security Act - in 2015. The British anti-terrorist acts are subject to regular review by an independent expert on terrorism (HM Government, 2015a; 2015b). 
sciendo Порівняльна професійна педагогіка 9(2)/2019 Comparative Professional Pedagogy 9(2)/2019

T. May considers the issue of ensuring national security to be a top priority. The prime minister has announced about the plans to introduce new anti-terror acts after the London Bridge attack in 2017. In her speech after the extraordinary meeting of the Cobra committee, Mrs May stated that Internet companies should be more actively involved in combating extremism. She also indicates that it is necessary to work with democratic governments in order to achieve international agreements on the regulation of cyberspace and, therefore, prevent the spread of extremism and terrorism. At the same time, the opponents of T. May criticize the proximity of conservatives to Saudi authorities and call for limiting the funding of Islamist organizations in the UK (HM Government, 2015a; 2015b).

Therefore, the conceptual analysis of the concept of national security in the UK shows that the country needs highly qualified specialists who are able to combat the today's challenges in the form of terrorism and military instability and ensure the protection of citizens at all levels. The Results section of the research, in turn, studies and analyzes the context of professional training for national security specialists at UK universities. The research findings, however, help to understand not only the specifics of such training but also outline its positive aspects which can be implemented in the context of higher education to combat terrorism and ensure the protection of individual countries, as well as the whole world.

\section{RESULTS}

To begin with, the Quality Assurance Agency (QAA) classifies national security studies as a field of the Subject Benchmark Statement for Politics and International Relations (2015). Indeed, it says, "degree programmes in peace or war studies, or in conflict studies, cut across conventional knowledge-based categories and their distinctive approaches to understanding; skills may need to draw on a wider range of materials and resources, including other Subject Benchmark Statements, to capture fully the specific character of their particular degree programmes" (QAA, 2015, p. 7).

Degree programmes in National Security involve studying the threats to both national and international security. The majority of higher education institutions offer various postgraduate programmes in National Security Studies (Terrorism/Security Studies; Defence and Security Studies), namely full-time master's degree, postgraduate certificates, diplomas and short duration courses in specific fields (e.g. global security, robotics, etc) (Defense and Security Courses in the UK, 2018).

Such UK universities as King's College London, the University of Leeds and Coventry University provide different postgraduate courses in national security studies, terrorism studies, military studies and forensics, international security strategies, defence and security systems. It must be noted that the graduates of such degree programmes have secure career opportunities within the government and other private or public defence organisations, defence manufacturing sector, including R\&D. In brief, the major learning outcomes of studying national security studies are the following: a) the knowledge of an individual country's national security policies and strategies; b) the ability to analyze some relevant security and defence-related issues; c) the ability to evaluate critically relevant approaches and support the decision making process (Defense and Security Courses in the UK, 2018).

King's College London offers National Security Studies MA, which aims to ensure the collaboration between the UK security policy practitioners and the representatives from the private sector, as well as postgraduate students who are interested in policies. The College guarantees that graduates will be able to obtain profound knowledge of national security issues in order to come up with cross-governmental responses to the challenges of national 
security. The degree programme also includes some conceptual and theoretical issues related to national security, as well as the aspects of UK national security analysis, including the analysis of approaches to national security in the international context (King's College London, 2018a).

Thus, the MA degree in National Security is divided into modules totalling 180 credits. The required modules are National Security Studies (40 credits) and Dissertation (60 credits). National Security Studies is a twenty-week programme, which is designed for students and practitioners who seek to enrich their knowledge about the processes of security policy-making and practices. As for its content characteristics, it covers the following aspects: the conceptual and practical policy aspects of the UK's attempts to implement a complex national security approach, as well as the history of the UK's modern strategies for ensuring national security; international comparative prospects for introducing some case studies on national security abroad; strategic and operational aspects of national security policymaking; the origins and development of the UK's modern approach to assuring national security and the conceptual history of policy-making processes in this particular field; an intellectual framework for comprehending the concept of national security, obtaining the knowledge about other important areas of national security policy (the effectiveness of political oversight arrangements; the UK's growing engagement with private organizations in realizing its objective in this policy area); the principles of national security; practical and conceptual challenges, including counter-terrorism, oversight of national security, cybersecurity; the key national security schemes and developments in this field, etc. (King's College London, 2018b).

As for the optional modules, there are the following choices: Cyber Security (40 credits); Intelligence \& Small Wars (40 credits); Chemical, Biological, Nuclear (CBN) Weapons in the Hands of States $(20$ credits), Homegrown Radicalization \& CounterRadicalization in Western Europe \& North America (40 credits).

Therefore, the graduates of the MA degree in National Security should be able to understand and critically analyze the origins, characteristics and prospects for the approach to assuring national security in the UK;

The University of Leeds offers Security, Terrorism and Insurgency MA. The degree programme is designed to teach students to analyze academically (counter-) terrorism and (counter-) insurgency and develop their expertise on various security challenges, including human rights, globalization and conflicts, climate change, religious radicalism, poverty, post-conflict reconstruction on global and regional levels. It is divided into compulsory and optional modules. The compulsory modules include Terrorism (30 credits), Insurgency (30 credits) and Dissertation (60 credits). After mastering them, the graduates will be able to engage in political polemics and media platitudes, comprehend the concept of terrorism and insurgencies as global, national and regional security threats, appreciate the political, legal and ethical issues, which may be faced by democracies and authoritarian regimes in developed and developing countries when they deal with terrorist and insurgent strategies and tactics (University of Leeds, 2018).

The range of optional modules is rather wide. Students have the opportunity to select such typical modules ( 30 credits each) as The Rise of China; The Politics of Brexit; Global Justice; Counter-Terrorism; American Foreign Policy; Conflict and Insurgency in Southeast Asia; The Politics of the Israel-Palestine Conflict; Popular Culture: World Politics, Society and Culture; Theoretical Approaches in International Relations; Civil War and Intrastate Conflict; Contemporary Politics of the Middle East; European Defense and Security Analysis; Conflict, Complex Emergencies and Global Governance. 
sciendo Порівняльна професійна педагогіка 9(2)/2019 Comparative Professional Pedagogy 9(2)/2019

Thus, University of Leeds (2018) prepares specialists who are able to understand the history of terrorism (state-sponsored terrorism, radical Islamism, preserve democratic liberties and develop counter-terrorism strategies, assess the need and effectiveness of the UK anti-terrorism legislation, as well as that of other countries and also analyze the political context and causes of terrorist violence and radicalization and the geopolitics of the Middle East.

The MA Peace and Conflict Studies offered by Coventry University is based on critical history and legacy of Coventry and promotes integrity and courage under today's conditions. It is designed to provide students with the knowledge of peace and conflict theories and practices and teach them how to apply this knowledge to peacebuilding in complicated situations. In addition, it aims to improve the knowledge, skills and competencies of those individuals who are ready to promote peace worldwide (Coventry University, 2018a).

The degree programme consists of three stages, namely the Postgraduate Certificate (60 credits), Postgraduate Diploma (120 credits) and Masters (180credits). It must be noted that each stage is built on the principle of blended learning, that is a mixture of face-to-face and distance learning. It allows students to combine studies and work, as well as personal commitments. Indeed, the three qualifications are sequential resulting in the full Master's degree. However, students are entitled to stop, pause or continue at each stage (Coventry University, 2018b).

The structure of the degree programme is as follows: the PC stage consists of Semesters 1 and 2. In Semester 1, students are to study two compulsory modules such as Peace, Conflict and Security in the $21^{\text {st }}$ Century ( 20 credits) and Philosophies of NonViolence and Reconciliation (20 credits) and one compulsory module in Semester 2 Peacebuilding: Theories in to Practice (20 credits); the PG Dip stage consists of Semesters 3 and 4. However, there are two different paths offered: Identity and Culture Pathway: in Semester 3 - Project Design and Planning (10 credits), Religion, Peace and Conflict (20 credits), in Semester 4 - Project Management in Practice (10 credits), Gender, Violence and Justice (20 credits) or Peace and Development Pathway: in Semester 3 - Project Design and Planning (10 credits), Comparative Peace Processes (20 credits), in Semester 4 Project Management in Practice (10 credits), Environment, Conflict and Sustainability (20 credits); the MA stage consists of Semesters 5 and 6: in Semester 5 - Research Design in CTPSR (10 credits, compulsory) and in Semester 6 - Dissertation in CTPSR (50 credits, compulsory).

According to this degree programme, the learning outcomes are the following: the graduates should be able to comprehend the nature and significance of peace and conflict studies as a multidisciplinary field which covers international relations, peace studies, war studies, sociology, psychology, anthropology, political science; single out and analyze the dynamics and resolution of conflicts in different theoretical contexts; understand the roles of gender, youth and non-state actors for creating peaceful societies at different levels, namely conflict prevention, peace and security architectures, alternative conflict management, transitional justice, etc.; show the awareness of the challenges which may occur in peacemaking peacebuilding practices at different levels; demonstrate profound knowledge about advanced methodological tools to evaluate their relevance in order to analyze specific research issues; think critically and analytically to evaluate one's arguments academic performance, as well as organizational and planning skill (Coventry University, 2018a; 2018b). 
Therefore, the UK aims for national security, prosperity, global reach and influence. It must be noted that they also believe that economic security goes hand-in-hand with national security. Since 2010 they have restored their economic security to live within their means. They now have one of the fastest-growing developed economies. They have chosen to invest in projecting our power, influence and values. These commitments constantly increase their security and safeguard their prosperity.

\section{CONCLUSIONS}

The conducted research proves that the UK seeks to identify and eliminate such threats as transnational organized crime, global instability and conflictogenity, global climate change, energy shortages, poverty, etc. The UK National Security Strategy is based on such key values as human rights, the rule of law, a lawful and responsible government, justice, freedom, tolerance and equal opportunity for all. As a result, the UK universities aim to diversify professional training of specialists in national security incorporating into the field such areas as peace or war studies, conflict studies, terrorism, insurgency, etc.

The content of professional training for national security specialists, namely masters, provided by King's College London, University of Leeds and Coventry University are characterized by the following features: adherence to the nation-wide principles of national security, the conceptual diversity of degrees (national security studies; peace and conflict studies; security, terrorism and insurgency), focus on humanities, professionoriented compulsory modules, a wide range of optional courses, flexible combination of study and work and personal commitments, research challenges, taking into account the dilemmas and challenges of globalization and integration, promotion of human rights, etc.

Based on the above-mentioned positive aspects of the UK experience in building the content of professional training for national security specialists, the following recommendations can be singled out to improve the content of professional training for such specialists at Ukrainian universities:

1. It is necessary to diversify the content of professional training for national security specialists incorporating such areas as (counter-) terrorism, cybersecurity, peace and conflict studies, insurgency, etc.

2. It is vital to make learning more flexible allowing students to combine study and work, and most importantly, personal commitments since they will be able to engage in both professional and personal development.

3. It is important to prepare future national security specialists to deal with the ever-increasing challenges of geopolitical situations, especially taking into account the difficult political situation in Ukraine and the threat to Ukrainian statehood.

4. It is crucial to promote human rights and equal opportunities for all in the context of assuring national security of the state in order to decrease potential political, economic, social threats and violence.

5. It is essential to teach future national security specialists to strengthen defence capabilities through enhancing their knowledge about policy-making and practices.

Further research should be aimed at studying the peculiarities of training national security specialists in NATO and the UN.

\section{REFERENCES}

1. Counter-Terrorism and Security Act. (2015). Retrieved from http://www. legislation.gov.uk/ukpga/2015/6/contents/enacted 
2. Coventry University. (2018a). Course Specification. MA (PG Cert, PG Dip) Peace and Conflict Studies. Retrieved from https://www.coventry.ac.uk/globalassets/ media/documents/registry/course-specs/fah/pg-fah/ma-peace-and-conflict-studies.pdf.

3. Coventry University. (2018b). Peace and Conflict Studies PgCert, PGDip, MA. Retrieved from https://www.coventry.ac.uk/course-structure/pg/2019-20/peace-and-conflict-studies-ma.

4. Defense and Security Courses in the UK. (2018). Retrieved from http://www.studyin-uk.in/study-guide/defence-and-security-courses-uk/.

5. HM Government. (2010). A strong Britain in an age of uncertainty: the National Security Strategy. London: The Stationery Office.

6. HM Government. (2015a). National Security Capability Review. Retrieved from https://assets.publishing.service.gov.uk/government/uploads/system/uploads/attachme nt_data/file/705347/6.4391_CO_National-Security-Review_web.pdf.

7. HM Government. (2015b). National Security Strategy and Strategic Defence and Security Review. A Secure and Prosperous United Kingdom. Retrieved from https://assets.publishing.service.gov.uk/government/uploads/system/uploads/attachment_da ta/file/555607/2015_Strategic_Defence_and_Security_Review.pdf.

8. King's College London. (2018a). Master of Arts in National Security Studies. Programme Specification. Retrieved from https:/www.kcl.ac.uk/aboutkings/ quality/academic/ prog/specs/201819pdfs/national-security-studies-ma.-2018-19.pdf.

9. King's College London. (2018b). National Security Studies MA. Retrieved from https://www.kcl.ac.uk/study/postgraduate/taught-courses/national-security-studies-ma.

10. QAA. (2015). Subject Benchmark Statement for Politics and International Relations. Retrieved from https:/www.qaa.ac.uk/docs/qaa/subject-benchmark-statements/ sbs-politics-15.pdf?sfvrsn=ee95f781_14.

11. Terrorism Prevention and Investigation Measures Act. (2011). Retrieved from https://www.legislation.gov.uk/ukpga/2011/23/contents.

12. University of Leeds. (2018). Security, Terrorism and Insurgency MA. Retrieved from https://courses.leeds.ac.uk/f821/security-terrorism-and-insurgency-ma\#section2. 